\title{
Mood System and Transitivity of the Airlines Slogan A Comparison of National and Regional Airlines
}

\author{
Eva Tuckyta Sari Sujatna ${ }^{1}$ \\ ${ }^{1}$ Faculty of Humanities, Universitas Padjadjaran, Indonesia \\ Correspondence: Eva Tuckyta Sari Sujatna, J1. Raya Bandung Sumedang Km.21 Jatinangor, Sumedang, \\ Indonesia. Tel: 62-22-779-6482. E-mail: evatuckyta@unpad.ac.id
}

Received: January 1, 2013 Accepted: March 29, 2013 Online Published: May 17, 2013

doi:10.5539/ijel.v3n3p42 URL: http://dx.doi.org/10.5539/ijel.v3n3p42

\begin{abstract}
Many studies applied the mood system and transitivity on the clauses, but a little are known that mood system and transitivity could also be applied on the slogans. As a descriptive analysis, this study tries to investigate the mood system and transitivity on the fourteen national airlines slogan and forty regional airlines slogan. The findings indicate firstly, the mood system found in the both national and regional airlines are declarative and imperative mood. Secondly, referring to the study, it is reported that the transitivity in the national airlines slogans found are material, mental, and relational processes while the regional airlines slogan found are material, mental, relational, and behavioural processes. Both of the national and regional airlines slogans: the major mood is declarative mood and the major process is relational process.
\end{abstract}

Keywords: mood system, transitivity, national airlines slogan, regional airlines slogan

\section{Introduction}

Language has three different metafunction of meanings. In line with Halliday and Matthiessen (2004) the metafunctions could be called simply as functions. The three functions of meanings are clause as message, clause as exchange, and clause as representation. The clause as message relates to theme and rheme while the two other functions; clause as exchange and clause as representation relate to mood and transitivity.

Based on the clause as exchange, every clause has mood and residue. The types of mood majorly could be categorized into indicative and imperative (Sujatna, 2013, pp. 51-56, Gerot and Wignell, 1995, pp. 38-41). The indicative itself is categorized into declarative, and interrogative while exclamative is a part of interrogative mood. Those types of mood are applied to indicate the mood type of the national and regional airline slogans in the data.

The transitivity or clause as representation is realized on the processes, participants, and circumstances. As the main element, the processes is indicated the participants and the circumstances. Every process in clauses is realized by verbs. In line with Halliday (1994 \& 2004), Deterding \& Poedjosoedarmo (2001), and Sujatna (2013) argue there are six different types of processes, They are material, mental, verbal, relational, behavioural, and existential processes. The types of processes are also found in the both of national and regional airline slogans.

Besides the mood types, both of national and regional airline slogans are investigated based on the transitivity.

Regional airlines that the writer means in this paper are from the Indonesia point of view. In this case, Indonesia is a national while others are regional countries. Regional countries refer to the South East Asia countries. They are Thailand, Malaysia, Philippines, Brunei, Singapore, Cambodia, Laos, Myanmar, and Vietnam. From the ten ASEAN countries (including Indonesia), it is found that not all countries have airlines with their slogans.

Many companies use their slogan to advertise their product or service to their customers. The slogans are used to introduce the product or service to their customers through their brands' message. Reece, Vanden Bergh, and Li, (1994, p. 41) argue that "The primary use of a slogan (also called taglines or signature lines) is to summarize the brand's message and to provide continuity from one advertising execution to another in a campaign". Magrath (1990) in Reece, Vanden Bergh, and Li (1994) believes that you should not underestimate the value of a good slogan as a key ingredient to establishing and maintaining a strong brand identity. Referring to those argumentations, it is a necessity to identify the type of clause and processes in describing the airlines slogan. 
This study conducted to figure out the mood system and transitivity of the national and regional airlines slogans. Many studies applied the mood system and transitivity on the clauses, but a little are known that mood system and transitivity could also be applied on the slogans.

\section{Method}

The method used in this research is descriptive analysis. It describes the types of mood and the transitivity of the Indonesian airlines, as the national airline, and Singapore, Malaysia, Philippines, Thailand, Myanmar, Cambodia, Vietnam, Brunei Darussalam, and Laos as the regional airlines or they are usually known as ASEAN countries.

The first step is collecting the airlines slogan further as the data. There are two classifications of slogans: the national airlines slogan and the regional airlines slogan. They are fourteen national airlines slogans and forty regional airlines slogans therefore the total is fifty four airlines slogans from the national and regional airlines. Then, the fourteen slogans, as the national airlines slogan, are identified into the type of mood system and their transitivity and do the same thing to the other of forty slogans as the regional airlines slogan.

\section{Theoretical Framework}

Clause as exchange relates to mood and residue. The elements of the mood itself are subject and finite. They indicate the types of mood. There are two major types of mood: indicative mood and imperative mood, in Sujatna (2013), Deterding \& Poedjosoedarmo, (2001), Martin, Matthiessen, \& Painter (1997) in line with Halliday (1994) and Halliday \& Matthiessen (2004). The indicative mood itself consists of declarative, interrogative, and exclamative mood. Other words, there are four types of mood: declarative, interrogative, exclamation, and imperative.

Talking about mood is talking about the interpersonal function. It is defined that the mood as the interpersonal, since there is an exchange in the dialogue in the mood system. The declarative mood elements, in Sujatna (2013), Halliday (2004), Deterding \& Poedjosoedarmo, (2001), Martin, Matthiessen, \& Painter (1997), Gerot \& Wignell (1995), are subject and finite as seen in example (1).

\begin{tabular}{|c|c|c|c|c|}
\hline (1) You & \multicolumn{2}{|c|}{ put } & it & there. \\
\hline Subject & Finite & Predicator & Complement & Adjunct \\
\hline \multicolumn{2}{|c|}{ Mood } & \multicolumn{3}{|c}{ Residue } \\
\hline
\end{tabular}

Sometimes the mood does not consist of subject and finite, but it can consist of mood adjunct as one of the elements of it. It is described in (2).

\begin{tabular}{|c|c|c|c|c|c|}
\hline (2) Surely & you & \multicolumn{2}{|c|}{ put } & it & there. \\
\hline Mood Adjunct & Subject & Finite & Predicator & Complement & Adjunct \\
\hline \multicolumn{3}{|c|}{ Mood } & \multicolumn{3}{c|}{ Residue } \\
\hline
\end{tabular}

The element of the imperative mood is different from the declarative mood. The imperative mood element can be no mood (without subject and finite) residue only as seen in (3) or with a mood (finite only) as seen in (4):

(3) Put it there! (Residue only)

(4) Don't put it there! (With a mood/ finite only)

Clause as representation relates to transitivity. Transitivity belongs to the ideational functions. It concerns the processes, participants, and circumstantial. Processes are the main element in English clauses, they are represented by verbs. Halliday (1994), Martin, Matthiessen, \& Painter (1997), Deterding \& Poedjosoedarmo (2001), Halliday \& Matthiessen (2004), Sujatna (2012) argue that there are six different types of processes: material, mental, verbal, relational, behavioural, and existential processes.

According to Gerot and Wignell (1995, p. 54), material process is process of doing, mental process is process of sensing, verbal process is process of saying, relational process is process of being, behavioural process is process of behaving, and existential process is process of existing.

\section{Mood System and Transitivity in Slogans}

Mood system relates to clause as exchange while transitivity relates to clause as representation. Both mood system and transitivity could be found in the slogans, in this study is airlines slogan.

Mood system indicated the types of mood. They could be declarative, interrogative, exclamation, or imperative mood. The study shows that both of the declarative mood as the part of indicative mood, and imperative could be found in the airlines slogan. 
Besides the mood system, the study also concerns the transitivity of the airline slogans. The transitivity which relates to clause as representation, concerns the processes, participants, and circumstances. There study shows there are four from the six different types of processes are found in the airlines slogan: they are relational, mental, behavioural, and material processes. The mental processes are found in the national and behavioural processes are found in the regional while the relational and material could be found in both national and regional airlines slogan.

\subsection{Mood System and Transitivity in National Airlines Slogan}

The national airlines slogan obtained are fourteen slogans. From the fourteen airlines slogan, there are sixteen clauses. Based on the result of the research, the mood systems found in the data are declarative mood and imperative mood while the transitivity found are material, mental, and relational processes as seen in the following table1.

Table 1. Mood system and transitivity in national airlines slogan

\begin{tabular}{llll}
\hline No & Slogans & Mood System & Transitivity \\
\hline 1 & We'll fly you safely & Declarative & Material \\
2 & We make people fly & Declarative/ & Material/ \\
& & Declarative & Material \\
3 & We Serve You Here ... There ... And Everywhere & Declarative & Material \\
4 & I Believe I can Fly & Declarative/ & Mental/ Material \\
& & Declarative & \\
5 & Love Is In The Air & Declarative & Relational \\
6 & Kartika Smile (is) - A Classic Way to Fly & Declarative & Relational \\
7 & (Pelita Air) (is) A Great Way to Fly & Declarative & Relational \\
8 & (Riau Airline) (is) The Spirit of Riau & Declarative & Relational \\
9 & Fly Is Cheap & Declarative & Relational \\
10 & (Batavia air) (is) Humility for Professionalism & Declarative & Relational \\
11 & (Sriwijaya Air) (is) Your Flying Partner & Declarative & Relational \\
12 & (Susi Air) (is) Your Complete Air Transport Solution For All of & Declarative & Relational \\
& Indonesia & & \\
13 & Get The Feeling & Imperative & Material \\
14 & Enjoy simplicity & Imperative & Mental \\
\hline
\end{tabular}

The table 1 describes that the fourteen slogans are the representation of the national airlines, Indonesia airlines. The fourteen slogans consist of twelve airlines slogan in clauses and two airlines slogan in clause complexes. It is described that there are sixteen mood system and transitivity since the clause complex slogans (2) and (4) consist of two mood systems and two processes.

\section{Mood System in National Airlines Slogan}

The mood system in the national airline slogans in data (1) - (14) are categorized into two mood system: declarative and imperative mood. They are fourteen declarative mood systems and two imperative mood systems.

\section{Declarative Mood}

The first category, declarative mood, is illustrated on data (1) - (12). There are totally fourteen clauses as declarative mood. The declarative mood has the elements subject + finite (or F) while the finite as the part of verbal group can be followed by a predicator as described the following analyses. 


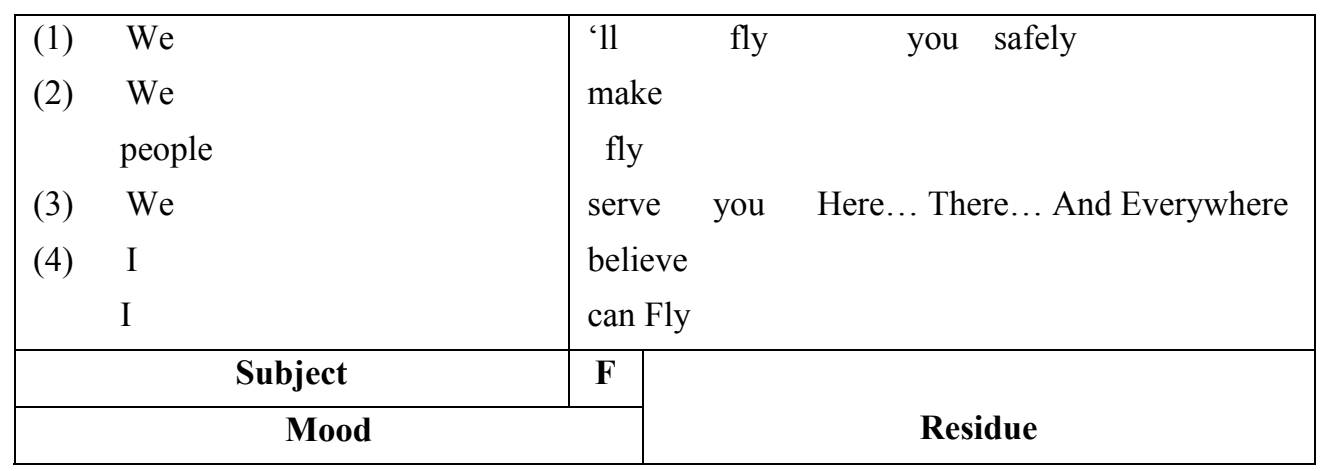

The slogans (1), (2), (3), and (4) from table 1 shows they are categorized into declarative mood since the mood elements are subject (we, people, and $I$ ) followed by finite ('ll, make, fly serve, believe, and can). The construction of the verbal group 'll fly (1), make and fly (2), serve (3), and believe and can fly (4) are verbal group consisting a finite and a predicator. The construction of verbal group does not only consist of a finite and a predicator but it can also consist of a finite only as described in data (5) - (12) as follows.

\begin{tabular}{|ll|l|l|}
\hline (5) & Love & Is & In The Air \\
$(6)$ & Kartika Smile & (is) & A Classic Way to Fly \\
(7) & (Pelita Air) & (is) & A Great Way to Fly \\
$(8)$ & (Riau Airline) & (is) & The Spirit of Riau \\
$(9)$ & Fly & is & Cheap \\
$(10)$ & (Batavia Air) & (is) & Humility for Professionalism Your Flying Partner \\
$(11)$ & (Sriwijaya Air) & (is) & Your Complete Air Transport Solution For All of \\
$(12)$ & (Susi Air) & (is) & Indonesia \\
\cline { 1 - 2 } & Subject & Finite & \\
\cline { 1 - 2 } Mood & \multicolumn{2}{c}{ Residue } \\
\hline
\end{tabular}

The eight data (5) - (12), as the second category of declarative mood, draw the verbal group can consist of a finite only, without a predicator. It is shown that five from eight subjects are implicit (as seen in (7), (8), (10), (11), and (12)). In terms of implicit subject or explicit subject, in declarative mood (totally from fourteen clauses) they are nine explicit subjects and five implicit subjects.

\section{Imperative Mood}

Besides the declarative mood, the slogans in the national airlines found as imperative mood. From the fourteen slogans which consist of sixteen mood systems, there are two imperative mood systems. Both of the imperative moods have no mood (subject and finite). The data illustrate they only have Residue since get (13) and enjoy (14) are predicator and the feeling (13) and simplicity (14) are complement, as seen in the following data.

\begin{tabular}{|l|l|l|}
\hline$(13)$ & Get & The Feeling \\
$(14)$ & Enjoy & Simplicity \\
\hline Predicator & Complement \\
\hline \multicolumn{3}{|c|}{ Residue } \\
\hline
\end{tabular}

\section{Transitivity in National Airlines Slogan}

From the fourteen slogans, they are twelve clauses and two clause complexes, so totally they are sixteen clauses. Relating to the transitivity, the sixteen clauses are categorized into three different processes; relational processes, material processes, and mental processes.

\section{Relational Processes}

The table 1 shows that the slogans are fourteen that consist of sixteen clauses (two of them are clause complexes). From the sixteen clauses, the major process is relational processes. They are (5) - (12) or eight clauses that relates to process of being that is why they are classified into relational processes. Based on the data, the verbs indicated the relational process is verb be (is). 


\begin{tabular}{|l|c|l|}
\hline (5) Love & Is & The Air \\
(6) Kartika Smile & (is) & A Classic Way to Fly \\
(7) (Pelita Air) & (is) & A Great Way to Fly \\
(8) (Riau Airline) & (is) & The Spirit of Riau \\
(9) Fly & Is & Cheap \\
(10) (Batavia air) & (is) & Humility for Professionalism \\
(11) (Sriwijaya Air) Partner & (is) & Your Flying \\
(12) (Susi Air) & (is) & Your Complete Air Transport Solution \\
& & For All of Indonesia \\
\hline Participant & Process: & Participant \\
& Relational & \\
\hline
\end{tabular}

\section{Material Processes}

From the fourteen slogans consisting sixteen clauses, there are six clauses as material processes, for the verbs will fly, make, fly, serve, can fly, and get. All the verbs in the slogans (1) - (4), and (13) as described in the following data are processes of doing as the indicator of material processes.

\begin{tabular}{|ll|l|l|l|}
\hline $\begin{array}{l}(1) \\
\text { (2) }\end{array} \quad$ We & 'll fly & you & safely \\
& people & fly & & \\
$(3) \quad$ We & Serve & You & Here ... There ... And Everywhere \\
$(4) \quad$ I & can Fly & & \\
$(13)$ (You) & Get & the feeling & \\
\hline Participant & Process: & Participant & Circumstance \\
& Material & & \\
\hline
\end{tabular}

\section{Mental Processes}

Only two clauses from the sixteen clauses (of the fourteen slogans) are mental processes. As the mental processes, the verbs believe (4) and enjoy (14) are related to verbs of cognition that is why they are classified into mental processes.

\begin{tabular}{|l|l|l|}
\hline $\begin{array}{l}\text { (4) I } \\
(14) \quad \text { (You) }\end{array}$ & $\begin{array}{l}\text { believe } \\
\text { enjoy }\end{array}$ & simplicity \\
\hline Participant & Process: Mental & Phenomenon \\
\hline
\end{tabular}

From the two data above, they have a slightly different structure. In data (4) the clause has no phenomenon while the data (14) the clause is subject less but it has a phenomenon, simplicity.

From the table 1, it can be summarized that the declarative mood is the major; it reaches to $86.6 \%$ while the imperative mood, as the minor mood, reaches to $13.4 \%$ as seen in chart 1 . The compositions in (\%) of the processes are dominated by Relational processes $(50 \%)$ followed by Material processes $(37.50 \%)$, and Mental processes $(12.50 \%)$. It is shown that the relational process is the major processes, followed by material process and mental process as drawn at chart 2 .

Chart 1 Mood System in National Airlines Slogan

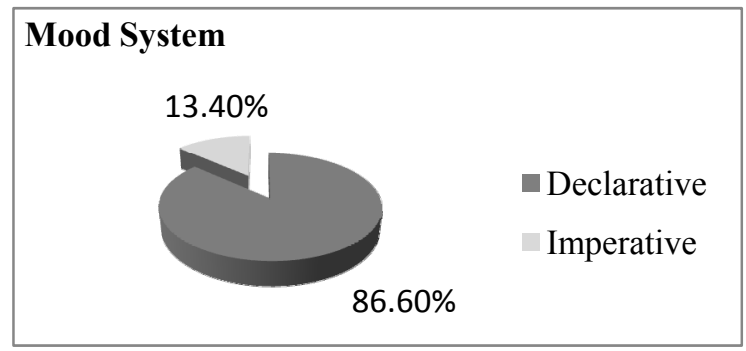

Chart 2 Transitivity in National airlines Slogan

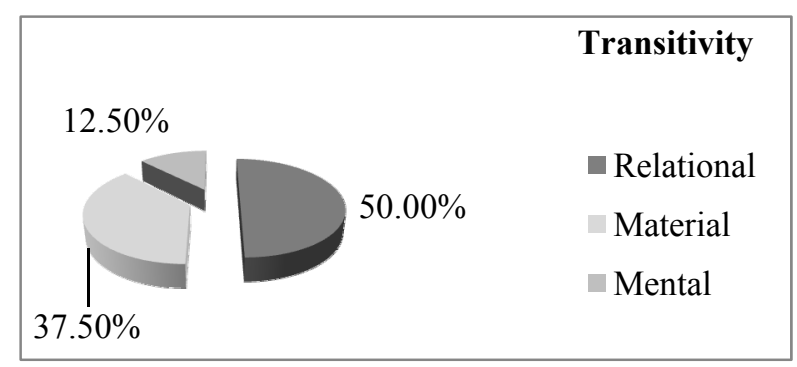




\subsection{Mood System and Transitivity in Regional Airlines Slogan}

The slogans are taken from official airlines websites in English version. From the collecting data, they are forty slogans consisting thirty seven clauses and three clause complexes, totally, they are forty three clauses. The forty three clauses are analyzed based on the mood system and transitivity of each clause. As the result of the study, it is shown that the mood system are declarative mood and imperative mood, while the transitivity are Relational processes, Material processes, and Behavioural processes as seen in table 2.

Table 2. Mood system and transitivity in international airlines slogan

\begin{tabular}{|c|c|c|c|}
\hline No & Slogans & Mood System & Transitivity \\
\hline 1 & Giving the world Asia's best & Declarative & Relational \\
\hline 2 & Treasure of Myanmar & Declarative & Relational \\
\hline 3 & Fly beyond your dreams & Imperative & Material \\
\hline 4 & Flying beyond Expectations & Declarative & Relational \\
\hline 5 & Safety, Reliability and Comfort & Declarative & Relational \\
\hline 6 & You're safe with us & Declarative & Relational \\
\hline 7 & Bring the World to Angkor Wat & Imperative & Material \\
\hline 8 & Proudly the national flag carrier & Declarative & Relational \\
\hline 9 & The Spirit of Cambodia & Declarative & Relational \\
\hline 10 & $\begin{array}{l}\text { For Safety, Comfort, Premium Air Travel to } \\
\text { Cambodia }\end{array}$ & Declarative & Relational \\
\hline 11 & You are safe with us & Declarative & Relational \\
\hline 12 & Smile with Silver Fly & Imperative & Behavioral \\
\hline 13 & Now Everyone Can Fly & Declarative & Material \\
\hline 14 & Now Everyone Can Fly Xtra Long & Declarative & Material \\
\hline 15 & Your community Airline & Declarative & Relational \\
\hline 16 & Community's Wings of Love & Declarative & Relational \\
\hline 17 & "MH" is Malaysian Hospitality & Declarative & Relational \\
\hline 18 & I'm going home & Declarative & Material \\
\hline 19 & Asia's First, Shining Through & Declarative & Relational \\
\hline 20 & Asia's most refreshing airline & Declarative & Relational \\
\hline 21 & It's time everyone flies & Declarative/ Declarative & Relational/ Material \\
\hline 22 & Excellent in service Our Guarantee... & Declarative & Relational \\
\hline 23 & Get The Real Deal & Imperative & Material \\
\hline 24 & where the world unwinds & Declarative & Relational \\
\hline 25 & A Great Way To Fly & Declarative & Relational \\
\hline 26 & Way Smarter & Declarative & Relational \\
\hline 27 & We Fly Smiles & Declarative & Material \\
\hline 28 & Do it by heart & Imperative & Material \\
\hline 29 & Thai Fly Fly Thai & Declarative/ Imperative & Material/ Material \\
\hline 30 & Smooth as Silk & Declarative & Relational \\
\hline 31 & Asia's Boutique Airline & Declarative & Relational \\
\hline 32 & Smooth Travelling & Declarative & Relational \\
\hline 33 & Sunny Airways, Always Smile & Declarative & Relational \\
\hline
\end{tabular}




$\begin{array}{llll}34 & \text { Wing of Asia } & \text { Declarative } & \text { Relational } \\ 35 & \text { Flying with Nature } & \text { Declarative } & \text { Relational } \\ 36 & \text { Air-Link to charming Places } & \text { Declarative } & \text { Relational } \\ 37 & \text { Discover the country with the sarus crane } & \text { Imperative } & \text { Material } \\ 38 & \text { Save More, Fly More } & \text { Imperative/ Imperative } & \text { Material/ Material } \\ 39 & \text { It's All About Choice } & \text { Declarative } & \text { Relational } \\ 40 & \text { Bringing Vietnamese Culture to the World } & \text { Declarative } & \text { Relational }\end{array}$

\section{Mood System in Regional Airlines Slogan}

The forty three clauses (from the forty slogans) are classified into two different mood systems; declarative mood and imperative mood. It is illustrated (in table 2) that the number of the declarative mood is the major and the imperative mood is the minor. There are thirty four declarative mood systems and nine imperative mood systems.

\section{Declarative Mood}

There are thirty four from forty three clauses are categorized into Declarative mood. Relating to the verbs, the Declarative mood is the major mood. It is categorized into two categories. The first category is the verbal group that only consists of finite only and the second is the category of verbal group containing a finite and a predicator.

Based on the result of the study, the first category are twenty eight clauses as declarative mood that the verbal group is a finite only. The following is the twenty eight mood systems as the declarative mood which the verbal group containing the finite only.

\begin{tabular}{|l|c|l|}
\hline (1) (Royal Brunei Airlines) & (is) & Giving the world Asia's best \\
(2) (Air Bagan) & (is) & Treasure of Myanmar \\
(4) (Air KBZ) & (is) & Flying beyond Expectations \\
(5) (Air Mandalay) & (is) & Safety, Reliability and Comfort \\
(6) You & 're & safe with us \\
(8) (Cambodia Angkor Air) & (is) & Proudly the national flag carrier \\
(9) (President Airlines) & (is) & The Spirit of Cambodia \\
(10) (TonleSap Airlines) & (is) & For Safety, Comfort, Premium Air Travel to Cambodia \\
(11) You & are & safe with us \\
(15) (Firefly) & (is) & Your community Airline \\
(16) (MASwings) & (is) & Community's Wings of Love \\
(17) "MH" & is & Malaysian Hospitality \\
(19) (Philippines Airlines) & (is) & Asia's First, Shining Through \\
(20) (Zest Air) & (is) & Asia's most refreshing airline \\
(21) It & is & time \\
(22) (Aero Majestic Airways) & (is) & Excellent in service Our Guarantee... \\
(24) (Silk Air) & (is) & where the world unwinds \\
(25) (Singapore Airlines) & (is) & A Great Way To Fly \\
(26) (Valuair) & (is) & Way Smarter \\
(30) (Thai Airways) & (is) & Smooth as Silk \\
(31) (Bangkok Airways) & (is) & Asia's Boutique Airline \\
(32) (Happy Air) & (is) & Smooth Travelling \\
(33) Sunny Airways & (is) & Always Smile \\
\hline
\end{tabular}




\begin{tabular}{|l|c|l|}
\hline (34) (Chrystal Thai Airlines) & (is) & Wing of Asia \\
(35) (Kan Air) & (is) & Flying with Nature \\
(36) (Nok Mini Airlines) & (is) & Air-Link to charming Places \\
(39) It & 's & All about Choice \\
(40) (Vietnam Airlines) & (is) & Bringing Vietnamese Culture to the World \\
\cline { 1 - 2 } Subject & Finite & \multicolumn{2}{|c}{ Residue } \\
\hline \multicolumn{2}{|c|}{ Mood } & \\
\hline
\end{tabular}

This second category is the rest, they are six clauses. The category has verbal group consisting a finite and a predicator. The verbs can (in (13) and (14) and am (18) are the finite while the verbs fly in (21), (27), and (28) are both finite and predicator.

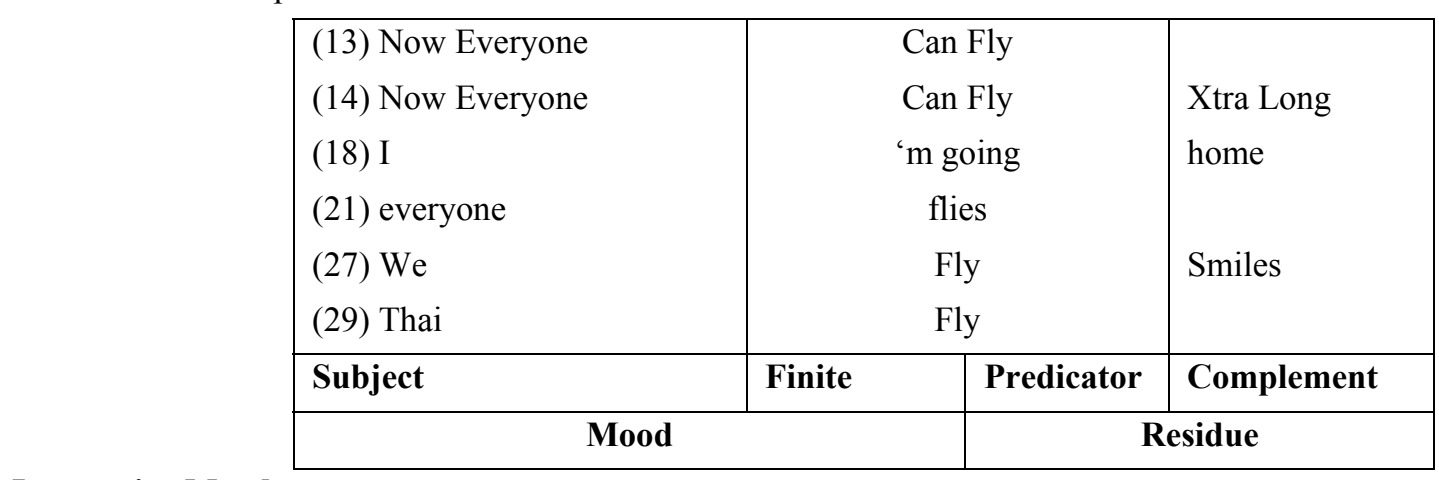

\section{Imperative Mood}

Besides the Declarative mood, there are other clauses as imperative mood systems. The number of data in the table 2 as the imperative mood is the rest of the Declarative mood. They are nine clauses as imperative mood systems from the forty three clauses. The verbs found in the imperative mood are fly (in (3), (4), (29), and (38), bring (7), smile (12), get (23), do (28), discover (37), and save (38). The imperative mood systems could be no mood (subject and finite) they consist of predicators and complements (residue) as described in the following analyses.

\begin{tabular}{|ll|l|}
\hline (3) & Fly & beyond your dreams \\
(7) & Bring & the World to Angkor Wat \\
$(12)$ & Smile & with Silver Fly \\
$(23)$ & Get & The Real Deal \\
$(28)$ & Do & it by heart \\
$(29)$ & Fly & Thai \\
$(37)$ & Discover & the country with the sarus crane \\
(38) & Save & more \\
& Fly & more \\
\hline \multicolumn{2}{|c|}{ Predicator } & Complement \\
\hline \multicolumn{2}{|l}{} \\
\hline
\end{tabular}

\section{Transitivity in Regional Airlines Slogan}

There are forty slogans containing thirty seven clauses and three clause complexes. Totally, they become forty three clauses in table 2. From the forty three clauses, they are three different processes: relational processes, material processes, and behavioural processes. The highest number is relational processes, then followed by material processes, and behavioural processes.

\section{Relational Processes}

As the highest number of processes, there are twenty eight clauses as relational processes. It has the same number with the declarative mood (the first category: the verbal group is the finite only) as described in the following analyses. 


\begin{tabular}{|c|c|c|c|}
\hline & (Royal Brunei Airlines) & (is) & Giving the world Asia's best \\
\hline (2) & (Air Bagan) & (is) & Treasure of Myanmar \\
\hline (4) & (Air KBZ) & (is) & Flying beyond Expectations \\
\hline$(5)$ & (Air Mandalay) & (is) & Safety, Reliability and Comfort \\
\hline (6) & You & 're & safe with us \\
\hline$(8)$ & (Cambodia Angkor Air) & (is) & Proudly the national flag carrier \\
\hline (9) & (President Airlines) & (is) & The Spirit of Cambodia \\
\hline$(10)$ & (TonleSap Airlines) & (is) & For Safety, Comfort, Premium Air Travel to \\
\hline (11) & You & are & Cambodia \\
\hline$(15)$ & (Firefly) & (is) & safe with us \\
\hline (16) & (MASwings) & (is) & Your community Airline \\
\hline (17) & "MH" & is & Community's Wings of Love \\
\hline (19) & (Philippines Airlines) & (is) & Malaysian Hospitality \\
\hline (20) & (Zest Air) & (is) & Asia's First, Shining Through \\
\hline$(21)$ & It & is & Asia's most refreshing airline \\
\hline (22) & (Aero Majestic Airways) & (is) & time \\
\hline (24) & (Silk Air) & (is) & Excellent in service Our Guarantee... \\
\hline$(25)$ & (Singapore Airlines) & (is) & where the world unwinds \\
\hline (26) & (Valuair) & (is) & A Great Way To Fly \\
\hline$(30)$ & (Thai Airways) & (is) & Way Smarter \\
\hline$(31)$ & (Bangkok Airways) & (is) & Smooth as Silk \\
\hline$(32)$ & (Happy Air) & (is) & Asia's Boutique Airline \\
\hline (33) & Sunny Airways & (is) & Smooth Travelling \\
\hline (34) & (Chrystal Thai Airlines) & (is) & Always Smile \\
\hline$(35)$ & (Kan Air) & (is) & Wing of Asia \\
\hline (36) & (Nok Mini Airlines) & (is) & Flying with Nature \\
\hline (39) & It & 's & Air-Link to charming Places \\
\hline$(40)$ & (Vietnam Airlines) & (is) & All about Choice \\
\hline & & & Bringing Vietnamese Culture to the World \\
\hline \multicolumn{2}{|c|}{ Participant } & $\begin{array}{c}\text { Process: } \\
\text { Relational }\end{array}$ & Participant \\
\hline
\end{tabular}

\section{Material Processes}

There are fourteen clauses from forty three clauses as material processes in table 2 . The verbs are indicated as material processes are fly (3), (13), (14), (21), (27), (29), (38), bring (7), go (18), get (23), do (28), discover (37), and save (38) as described in the following analyses.

\begin{tabular}{|ll|l|l|}
\hline$(3)$ & (You $)$ & Fly & beyond your dreams \\
$(7)$ & (You $)$ & Bring & the World to Angkor Wat \\
$(13)$ & Now Everyone & Can Fly & \\
$(14)$ & Now Everyone & Can Fly & Xtra long \\
$(18)$ & I & am going & home \\
$(21)$ & Everyone & flies & \\
$(23)$ (You $)$ & Get & the real deal \\
$(27)$ & We & Fly & Smiles \\
\hline
\end{tabular}




\begin{tabular}{|ll|l|l|}
\hline (28) & (You) & Do & it by heart \\
$(29)$ & Thai & Fly & \\
& (You) & Fly & Thai \\
$(37)$ & (You) & Discover & the country with the sarus crane \\
$(38)$ & (You) & Save & more \\
& (You) & Fly & more \\
\hline Participant & Process: Material & Participant \\
\hline
\end{tabular}

\section{Behavioural Processes}

The table 2 says, from the forty three clauses, there is only one behavioural process. The verb indicates the behavioural process is smile (12), as described in the following analysis.

\begin{tabular}{|l|l|l|}
\hline$(12)($ You $)$ & Smile & with silver Fly \\
\hline Participant & Process: Behavioural & Circumstance \\
\hline
\end{tabular}

From the table 2, it can be summarized that the declarative mood is the major; it reaches to $79 \%$ while the imperative mood, as the minor mood, reaches to $21 \%$ as seen in pie chart 3 . The compositions in (\%) of the processes are dominated by Relational processes $(65.11 \%)$ followed by Material processes $(32.57 \%)$, and Behavioural processes $(2.32 \%)$. It is shown that the relational process is the major processes, followed by material process and mental process as drawn at pie chart 4 .

Chart 3 Mood System in Regional Airlines Slogan

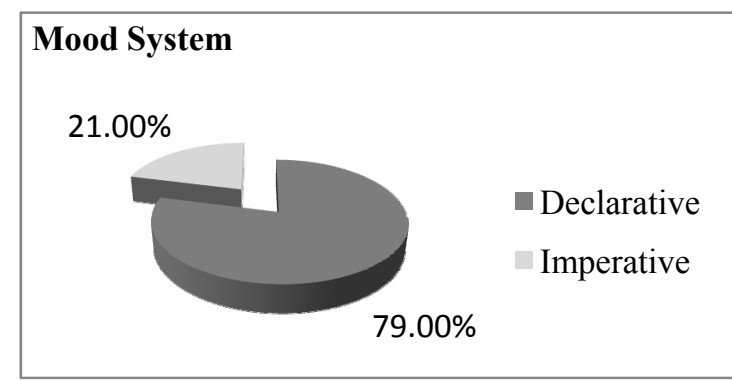

Chart 4 Transitivity in Regional Airlines Slogan

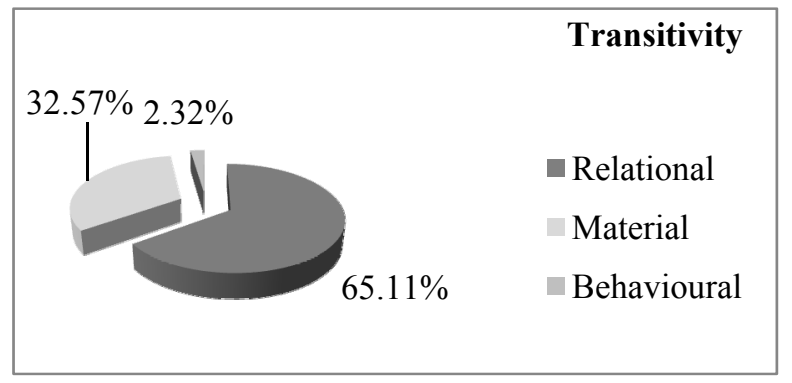

\section{Conclusion}

The findings indicate firstly, the mood system found in the both national and regional airlines are declarative mood systems as the major and imperative mood systems as the minor. Secondly, referring to the study, it is reported that the transitivity in the national airlines slogan are relational, material, and mental processes, while the regional airlines slogan are relational, material, and behavioural processes. Both of the national and regional airlines slogans: the major is declarative mood systems and the major process is relational process as summarized in the following table 3 .

Table 3. Mood systems and transitivity of national and regional airlines slogan

\begin{tabular}{|c|c|c|c|c|c|c|c|c|c|}
\hline \multicolumn{4}{|c|}{ National (16 clause from 14 slogans) } & \multicolumn{4}{c|}{ Regional (43 clauses from 40 slogans) } \\
\hline \multicolumn{2}{|c|}{ Mood System } & \multicolumn{3}{|c|}{ Transitivity } & \multicolumn{3}{c|}{ Mood System } & \multicolumn{3}{c|}{ Transitivity } \\
\hline Declarative & Imperative & Relational & Material & Mental & Declarative & Imperative & Relational & Material & Behavioural \\
\hline 14 & 2 & 8 & 6 & 2 & 34 & 9 & 28 & 14 & 1 \\
\hline
\end{tabular}

\section{References}

Deterding, D., \& Poedjosoedarmo, G. R. (2001). Grammar of English. Singapore: Prentice Hall.

Gerot, L., \& Wignell, P. (1995). Making Sense of Functional Grammar (2nd ed.). Sydney: Gerd Stabler.

Halliday, M. A. K. (1994). An Introduction to Functional Grammar (2nd ed.). London: Edward Arnold. 
Halliday, M. A. K., \& Matthiessen, C. M. I. M. (2004). An Introduction to Functional Grammar (3rd ed.). London: Edward Arnold.

Martin, J. R., Matthiessen, C. M. I. M., \& Painter, C. (1997). Working with Functional Grammar. London: Edward Arnold.

Morrish, J. (2004). The Slogan Doctor Nike: Just Do It. Management Today, 2004(Sept), 19.

Reece, B. B., Bergh, B. G. V., \& Li, H. (1994). What Makes a Slogan Memorable and Who Remembers It. Journal of Current Issues and Research in Advertising, 16(2), 41-57. http://dx.doi.org/10.1080/10641734.1994.10505018

Sujatna, E. T. S. (2012). Applying Systemic Functional Linguistics to Bahasa Indonesia. International Journal of Linguistics, 4(2), 134-146. http://dx.doi.org/10.5296/ijl.v4i2.1506

Sujatna, E. T. S. (2012). Sundanese Verbs in Mental Processes: A Systemic Functional Linguistics Approach. International Journal of Linguistics, 4(4), 468-476. http://dx.doi.org/10.5296/ijl.v4i4.2577

Sujatna, E. T. S. (2013). Understanding Systemic Functional Linguistics. Bandung: Unpad Press. 